\title{
Environmental Flow Estimation Using Hydrological and Hydraulic Methods for the Quindío River Basin: WEAP as a Support Tool*
}

\section{Estimación de Caudales Ecológicos mediante Métodos Hidrológicos e Hidráulicos para la Cuenca del Río Quindío Usando WEAP como Herramienta de Apoyo}

DOI: http://dx.doi.org/10.17981/ingecuc.11.2.2015.04

Research article - Reception date: August 5, 2014 - Acceptance date: August 27, 2015

Gabriel Lozano Sandoval

Master in Civil Engineering with specialization in Environmental Engineering,

Universidad del Quindío/Centro de Investigación, Desarrollo y Estudio del Recurso Hídrico y el Ambiente (CIDERA).

Armenia (Colombia).galozano@uniquindio.edu.co

Elkin Aníbal Monsalve Durango

Master in Sanitary and Environmental Engineering, Universidad del Quindío/Centro de Investigación,

Desarrollo y Estudio del Recurso Hídrico y el Ambiente (CIDERA). Armenia (Colombia).

elkinmonsalve@uniquindio.edu.co

Pedro León García Reinoso

Master in Civil Engineering with specialization in Hydrologic Resources, Universidad del Quindío/Centro de Investigación, Desarrollo y Estudio del Recurso Hídrico y el Ambiente (CIDERA). Armenia (Colombia). pedrogarcia@uniquindio.edu.co

Cesar Augusto Rodríguez Mejía

Civil Engineer, Universidad del Quindío/Centro de Investigación,

Desarrollo y Estudio del Recurso Hídrico y el Ambiente (CIDERA). Armenia (Colombia). carodriguezm@uniquindio.edu.co

Juan Pablo Gómez Ospina

Specialist in Hydraulic and Environmental Engineering, Universidad del Quindío/Centro de Investigación, Desarrollo y Estudio del Recurso Hídrico y el Ambiente (CIDERA). Armenia (Colombia). juanpablogoos22@gmail.com

Héctor Javier Triviño Loaiza

Civil Engineer, Universidad del Quindío/Centro de Investigación, Desarrollo y Estudio del Recurso Hídrico y el Ambiente (CIDERA). Armenia (Colombia).ing_hectortrivino@hotmail.es

To reference this paper:

G. Lozano Sandoval, E. A. Monsalve Durango, P. L. García Reinoso, C.A. Rodríguez Mejía, J.P. Gómez Ospina and H.J. Triviño Loaiza, "Environmental Flow Estimation Using Hydrological and Hydraulic Methods for the Quindío River Basin: WEAP as a Support Tool," INGE CUC, vol. 11, no. 2, pp. 34-48, 2015. DOI: http://dx.doi.org/10.17981/ingecuc.11.2.2015.04

* Research paper derived from the research project "Estimación de caudales ecológicos mediante metodologías hidrológicas e hidráulicas en la cuenca del río Quindío”. Funded by Universidad del Quindío and the Corporación Autónoma Regional del Quindío 'CRQ'. This project was developed under the administrative agreement No. 027 of 2010 signed between the University of Quindío and the CRQ. Start date: February, 2010. Completion date: June, 2011 


\begin{abstract}
In the Quindío river basin, there are different uses of water which, in some dry periods of the year, threaten aquatic ecosystems. This project sought to estimate an environmental flow regime for the Quindío river basin. Different hydrologic and hydraulic methods were implemented; the 7Q10, Q95, IDEAM, Q97.5, and Q90 are highlighted. Users concerned with the results of this research are: the Regional Autonomous Corporation of Quindío (CRQ), the public utility companies of water and sewage, and scholarly communities and researchers related to the study of water resources. In conclusion, the Q95 method allows obtaining environmental flow regimes on a monthly basis capable of adapting to the hydrological variability of the natural regime.
\end{abstract}

Keywords - Environmental Flow, Hydrologic Methods, Hydraulic Methods, Natural Flow Regime, Hydrological Restitution, Water Resource, Rainfall-Runoff Model, WEAP.
Resumen- En la cuenca del río Quindío existen diferentes aprovechamientos de agua, los cuales, en algunos periodos secos del año, ponen en riesgo al ecosistema acuático. Con este proyecto se buscó estimar un régimen de caudales ecológicos para la cuenca del río Quindío. Diferentes métodos hidrológicos e hidráulicos fueron implementados destacando el 7Q10, el Q95, el IDEAM, el Q97.5 y el Q90. Los usuarios involucrados con los resultados de esta investigación son: la Corporación Autónoma Regional del Quindío (CRQ); las empresas de servicios públicos de acueducto y alcantarillado; y la academia y los investigadores relacionados con el estudio del recurso hídrico. Se concluye que de los métodos hidrológicos e hidráulicos empleados, el Q95 permite obtener un régimen de caudales ambientales a escala mensual que se ajuste a la variabilidad hidrológica del régimen natural.

Palabras Claves - Caudal Ecológico, Métodos Hidrológicos, Métodos Hidráulicos, Régimen de Caudal Natural, Restitución Hidrológica, Recurso Hídrico, Modelo Lluvia Escorrentía, WEAP.

\section{Introduction}

Water is required by every living species, however, it is finite and less is its amount as freshwater [1]. Additionally, water is vital for the socioeconomic development of a city; even more when this progress is unrestrained and produces a great diversity of uses for water, hence, fostering its quality detriment, as well as the gradual harm of the rest of the natural resources in a hydrographic basin.

For this reason, a sustainable development of cities regarding natural resources use, particularly water, is considered nowadays so as to prevent a critical level of resource conservation. With the intention of achieving this objective, planning and comprehensive management of water usage is necessary. Support tools, methods, and economic and legal instruments become important means for decision making when establishing sustainable development procedures of a city.

One of the most relevant topics concerning comprehensive management of water resources is the determination of environmental flows, which refers to the flow needed after being used (natural regime modification) in order to support ecological functions and dynamics of the different biotic communities of the fluvial ecosystem.

Environmental flow estimation analysis is incipient in Colombia, nonetheless, some methods have been proposed, for instance, by the Institute of Hydrology, Meteorology and Environmental Studies -IDEAM [2]. The National University of Colombia -UNAL and the Ministry of Environment, Housing and Territorial Development pose a method for the estimation of environmental flows in licensed projects [3]. In [4], several important techniques are put forth so as to assess environmental flows in accordance with the regulations for sustainable water basins. Likewise, in [5] an application for the determination of reliable environmental flows in Colombia is illustrated using a case study of the Palacé River in the Department of Cauca. Even though some studies have been performed, the Colombian and Latin American scenario still lacks a suitable amount of studies of this sort; therefore, current water use licensing granted by environmental authorities lack a proper hydrologic analysis and estimation of the environmental flow downstream from each usage zone.

In the particular case of the Quíndio river basin, several water usage zones are located along the river, mainly for household use, energy generation, and industry. During some dry periods of the year, these require a considerable flow and put the ecosystem and the adequate movement of the river at risk downstream from these areas.

Therefore, the main objective of this study is the estimation of environmental flows through hydrological and hydraulic methods for the Quindío river basin in order to contribute towards an efficient decision making, planning, and management of water resources in the Department of Quindío.

For the estimation of environmental flows in this basin, different hydrological and hydraulic methods will be implemented. To achieve this, a methodological approach is implemented for this study: first, a literature review of international and regional sources; then, the collection, processing, and analysis of primary and secondary data; next, the restoration of the natural flow regime and the environmental flow estimation through the suggested methods; and finally, the analysis of results and conclusions of this study. 
With this project, the social and scientific context is being directly modified, since this is the first research related to environmental flows that is developed locally. From a social stance, provides a support tool for water usage planning in order to help environmental authorities, mainly, in decisionmaking processes in order to foster the achievement of a suitable level of ecological balance in the different sections of the river by allowing a rational use of this resource by means of the compliance of sustainable development standards for aquatic ecosystems, hence, improving the quality of life of users and the community in general. From a scientific standpoint, this study strengthens the lines of research of Universidad del Quindío's CIDERA group through the dissemination and transference of knowledge regarding environmental flows and the promotion of young researchers.

For this project, different methods the determination of environmental flows in the Quindío river basin were applied taking into account water uses to date and foreseeing the use of this resource in the Department. It is strongly recommended to contemplate the feasibility of building a dam in the $\mathrm{Na}$ varco River and a new pumping station for the EPA public utility company.

\section{Methodology}

The aim of this study is the estimation of environmental flows in the Quindío river basin, for this purpose, several hydrological and hydraulic methods will be applied. Finally, considering the hydroclimatologic conditions of this region, a suitable environmental flow will be recommended to the environmental authorities.

In the hydrologic methods, the environmental flow is deduced from the hydrologic data gathered using different mechanisms (flow duration, mean discharge percentage, time series analysis, etc.). These may encompass diverse formulae and hydrologic indicators, unique variables for the basin, or hydraulic, biological and/or geomorphological considerations. The indicators are chosen based on a combination of statistical analyses and direct observation of rivers with similar hydrologic and/or ecological conditions [6].

As for hydraulic methods, changes in simple hydraulic variables (wetted perimeter, maximum depth, mean flow velocity) are measured in one or multiple sections, based on flow variations, in order to establish relations with the habitat of selected species, which may be affecting them. Sections are chosen in places where flow maintenance is more critical or where habitats are more sensitive to these flow reductions [6].

Table I and II list the different hydrologic and hydraulic methods applied in this estimation study.
Table I. Hydrologic Methods

\begin{tabular}{|c|c|}
\hline Method & Description \\
\hline $\begin{array}{l}\text { Matthey } \\
\text { Method }\end{array}$ & $\begin{array}{l}\text { Estimates the minimum discharge based on } \\
\text { the flow present in at least } 300 \text { days of the } \\
\text { year (Q300 from the flow duration curve) }\end{array}$ \\
\hline $\begin{array}{l}\text { Dirección } \\
\text { General } \\
\text { de Obras } \\
\text { Hidráulicas } \\
\text { - Spain } \\
\text { (DGOH } \\
\text { Method) }\end{array}$ & $\begin{array}{l}\text { Determines the minimum permanent } \\
\text { instream discharge to a } 10 \% \text { of the } \\
\text { interannual mean discharge. }\end{array}$ \\
\hline $\begin{array}{l}\text { Swiss } \\
\text { Method }\end{array}$ & $\begin{array}{l}\text { Implements empiric formulae for the } \\
\text { determination of the minimum discharge } \\
\text { distinguishing between fish hatchery water } \\
\text { and other water. }\end{array}$ \\
\hline $\begin{array}{l}\text { Texas } \\
\text { Method }\end{array}$ & $\begin{array}{l}\text { Establishes a variable monthly mean } \\
\text { percentage. In this way, hydrological and } \\
\text { biological conditions of non-salmonid } \\
\text { streamflows are considered taking into } \\
\text { account certain river species as indicators, } \\
\text { as well as an hydrological index that reveals } \\
\text { inflow flow regimes. }\end{array}$ \\
\hline Utah Method & $\begin{array}{l}\text { Uses the minimum monthly measurements } \\
\text { to determine a monthly flow regime in which } \\
\text { the minimum discharge for each month is the } \\
\text { minimum measurement registered during a } \\
\text { suitable time series. }\end{array}$ \\
\hline $\begin{array}{l}\text { NGPRP } \\
\text { Method } \\
\text { (Northern } \\
\text { Great Plains } \\
\text { Resource } \\
\text { Program) }\end{array}$ & $\begin{array}{l}\text { Uses time series of monthly mean discharges } \\
\text { and defines three groups based on certain } \\
\text { probabilities: low flows, normal flows, and } \\
\text { high flows. }\end{array}$ \\
\hline $\begin{array}{l}\text { Hoppe } \\
\text { Method }\end{array}$ & $\begin{array}{l}\text { It is based on the flow duration curve and the } \\
\text { biological requirements of fish hatcheries, } \\
\text { mainly trout populations of the rivers in } \\
\text { Colorado. The method establishes three } \\
\text { importantan flow levels for fish according } \\
\text { to three basic objectives: food and shelter, } \\
\text { reproduction, and flow restoration. }\end{array}$ \\
\hline $\begin{array}{l}\text { Flow } \\
\text { Duration } \\
\text { Curves } \\
\text { Method }\end{array}$ & $\begin{array}{l}\text { Shows the percentage of time that a discharge } \\
\text { of a river is present in each month of the year } \\
\text { by using daily values, hence, determining } \\
\text { a flow regimen, which is a considerable } \\
\text { improvement for keeping a fixed discharge } \\
\text { during the year. }\end{array}$ \\
\hline $\begin{array}{l}\text { Asturian } \\
\text { Method }\end{array}$ & $\begin{array}{l}\text { Establishes three protection levels for } \\
\text { streamflows; the environmental flow is } \\
\text { estimated using the Q347, obtained through } \\
\text { the formula accepted by Swiss regulations. }\end{array}$ \\
\hline $\begin{array}{l}\text { Navarrese } \\
\text { Method }\end{array}$ & $\begin{array}{l}\text { Uses both the Swiss and French regulations } \\
\text { to obtain the environmental flow. A } \\
\text { distinction is made based on whether fish } \\
\text { population is salmonid or cyprinid. }\end{array}$ \\
\hline $\begin{array}{l}\text { Basque } \\
\text { Method }\end{array}$ & $\begin{array}{l}\text { It seeks to maintain biodiversity. Diversity } \\
\text { is measured by the number of taxa within } \\
\text { a benthic macroinvertebrate community; } \\
\text { however, despite this biological component, it } \\
\text { is essentially a mathematical method. }\end{array}$ \\
\hline 7Q10 Method & $\begin{array}{l}\text { The environmental flow corresponds to the } \\
\text { value of the lowest } 7 \text {-day average flow that } \\
\text { occurs on average once every } 10 \text { years. }\end{array}$ \\
\hline Q95 Method & $\begin{array}{l}\text { It is the flow discharge which can be expected } \\
\text { to be exceeded } 95 \% \text { of the time in a year. }\end{array}$ \\
\hline
\end{tabular}

Source: [1] 
Table II. Hydraulic Methods

\begin{tabular}{|c|c|}
\hline Method & Description \\
\hline $\begin{array}{c}\text { Tennant or } \\
\text { Montana } \\
\text { Method }\end{array}$ & $\begin{array}{l}\text { For its application, three hydraulic variables } \\
\text { are analyzed. They are considered to be fun- } \\
\text { damental for fish permanence. These are: wet- } \\
\text { ted perimeter percentage regarding riverbed } \\
\text { width, depth, and average velocity. }\end{array}$ \\
\hline $\begin{array}{l}\text { Montana } \\
\text { Method }\end{array}$ & $\begin{array}{l}\text { It is a simpler version of the Tennant Method } \\
\text { and even easier to apply. It only considers three } \\
\text { inflow discharges obtained from the interann- } \\
\text { al module (Qan). }\end{array}$ \\
\hline $\begin{array}{l}\text { Tessman } \\
\text { Method }\end{array}$ & $\begin{array}{l}\text { It is a modification of Montana's method (Bo- } \\
\text { zeman, 1976). It estimates the environmental } \\
\text { flow by comparing a determined percentage of } \\
\text { the mean interannual flow rate (Qan) of the dis- } \\
\text { charge to the mean monthly flow rate (Qmon). } \\
\text { Daily or monthly flow rates can be used; for the } \\
\text { former case, final values obtained are higher. } \\
\text { It is an improvement of the Tennant Method } \\
\text { because it estimates environmental flows for } \\
\text { every month of the year. }\end{array}$ \\
\hline
\end{tabular}

Source: [1]

As presented, for environmental flow estimation using hydrologic and hydraulic methods, hydroclimatological data collection, processing and analysis (on a daily basis preferably) is necessary. Likewise, field trips should be performed for primary data collection from flows during low water season and determine hydraulic variables such as the river's width, wetted perimeter, mean flow velocity, among others.

Some of the stages developed in this study are outlined hereunder:

\section{Stage I. Preliminary Tasks}

- Literature Review: This step allowed establishing which methods have been applied in the country and the world, in this way, a comparison of different strategies and procedures used in researches of various river basins was executed.

- Required Data Collection: Hydrologic and meteorological data provided by the regional Autonomous Corporation of Quindío (CRQ) was used. Likewise, Armenia's public utility company EPA and the Multi-purpose company of Calarcá also provided information regarding discharge time series, precipitation levels, temperature, and evapotranspiration, among other climate variables. Additionally, macrometering information from some sub-basin catchments used for the restoration of natural flow regimes was attained.

- Inspection of the studied site and primary data collection: Field trips during low water seasons (March, April, July, and August) to gather primary data were vital to measure flow rate, define hydraulic variables, georeference flowmetering sites, and water catchment structures.

\section{Stage II. Data Analysis}

- Digitalization of collected data for more efficient handling of information.

- Data compleition and validity analysis of secondary data (mainly hydrometereological information) using double mass curve technique.

\section{Stage III. Restoration of Natural Regime}

For environmental flow calculation is necessary to determine the Natural Flow Regime -NFR, i.e. ponder the scenario in which there is no water catchment in the river for human usage. This criterion demands a hydrological modeling, as well as a modeling of the water resource system in the river basin in order to lay out this natural scenario. WEAP (Water Evaluation and Planning System) is a tool that facilitates this process.

WEAP system is a computing tool for the comprehensive planning of water resources. It provides an integrated, flexible, and user-friendly framework for planning and analyzing policies related to water resources. WEAP works using the basic principle of mass balance that can be used for municipal and agricultural systems, either for one basin or for complex basin systems. Additionally, WEAP can simulate an ample range of natural and intervened components of these systems including rainfall-runoff, baseflow and groundwater recharge by precipitation, demand analysis by sections, water conservation, water rights and allocation priority, dam operations, hydroelectric power generation, pollution monitoring and water quality, among others [7].

Finally, this stage encompasses the following steps:

- Hydrologic modeling construction of the Quindío river basin using WEAP's Decision Support System (DSS)

- Execution and calibration of the hydrologic model for the Quindío basin

- Restoration of the natural flow regime of the Quindío river basin.

\section{Stage IV. Methods for Environmental Flow Estimation}

For the estimation process, hydrologic and hydraulic methods based on mathematical or statistical processes are applied. Hydrologic data will be processed in different manners: flow duration, mean discharge percentage or time series analyses, among others [4] [6].

The hydrologic methods implemented in this study have been applied to different rivers in the world. In the case of the Quindío River and 
as an objective of this research, these methods will be implemented in order to select and recommend the most suitable for the unique hydroclimatological conditions of this basin. So as to estimate the environmental flow, these hydrologic and hydraulic method need to be applied in NFR conditions, hence, for the Quindío basin this condition needs to be determined, this is, the assumption of a non-exploitation condition of any sort.

The estimation methods implemented in this study were presented in Table I and II.

\section{Stage V. Result Analysis}

Based on the results obtained with the different estimation methods, the most appropriate ones regarding the unique hydroclimatological, hydraulic and habitat conditions of the basin will be determined.

\section{Materials}

\section{A. Description of the Region Analyzed}

Quindío River is one of the two rivers comprising La Vieja River, a great fluvial axis and settlement of towns. The Quindío river basin is located in the central part of the Colombian west under the jurisdiction of the Department of Quindío (Fig. 1) and directly influenced by the municipalities of Armenia, Calarcá, Salento, Córdoba, and Buenavista [8]. Additionally, two municipalities which do not belong to the region studied but benefit from the water of this river are Circasia and La Tebaida. The population that benefits from the Quindío River is presented in Table III.
Table III. Population Favored by the Quindío River

\begin{tabular}{|c|c|c|}
\hline \multicolumn{3}{|c|}{ Population Census According to DANE 2005 } \\
\hline Municipality & $\begin{array}{c}\text { Population in the } \\
\text { Municipal Capital }\end{array}$ & $\begin{array}{c}\text { Other } \\
\text { Population }\end{array}$ \\
\hline Salento & 3.494 & 3.507 \\
\hline Armenia & 265.020 & 7.554 \\
\hline Circasia & 19.543 & 7.162 \\
\hline Calarcá & 54.634 & 16.966 \\
\hline Buenavista & 1.173 & 1.781 \\
\hline Córdoba & 2.897 & 2.341 \\
\hline La Tebaida & 29.955 & 2.793 \\
\hline Total & 376.716 & 42.104 \\
\hline
\end{tabular}

Source: [8]

\section{B. Climate}

The Department is characterized by its diversity of thermal floors and high rainfall rate which ranges from $1900 \mathrm{~mm}$ and $2800 \mathrm{~mm}$ in the year [9]. There is a small area of transitional semihumid to semi-dry climate in the northwest, near La Vieja River. To carry out this study, data from the CRQ hydrometereology stations --hydrology and meteorology stations El Bosque, La Playa, Bocatoma EPA, Navarco, La Picota, Calle Larga, Centro de la Guadua, La Sierra, and Edén and limnimetric and limnigraphic stations Bocatoma EPA, Palestina Baja, Calle Larga y Centro de la Guadua- location along the river basin [9]. During the hydroclimatological analysis of this information, the bimodal behavior pattern of the Colombian Andean region was identified: the most humid months are April, May, October, and November, and the driest are January, February, July, and August.

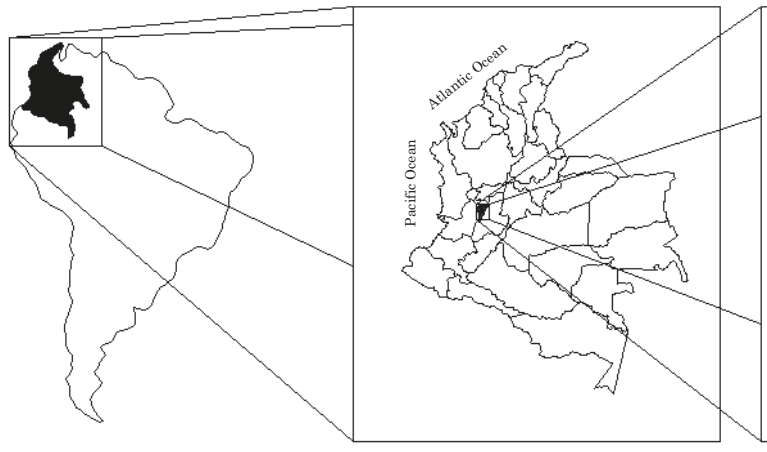

SOUTHAMERICA
REPUBLIC OF COLOMBIA

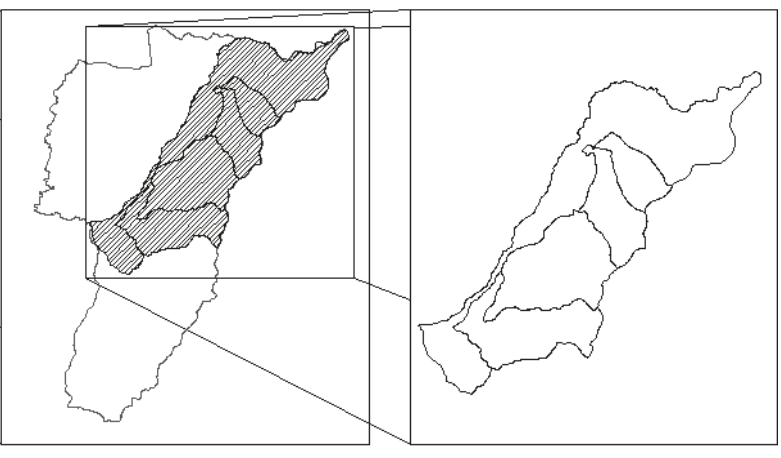

DEPARTMENT OF QUINDÍO

QUINDÍO RIVER SUB-BASIN

Fig. 1. Location of the Region Studied.

Source: Author 


\section{Surface Water Supply}

The hydrographic network of the Quindío River is mainly comprised of the main stream and its tributaries: Navarco, Boquerón, Santo Domingo, and Verde Rivers. The water supply from each of these is set forth in Table IV.

Table IV. Water Supply in the Quindío River Basin

\begin{tabular}{|c|c|}
\hline \multirow{2}{*}{ River } & Water Supply \\
\cline { 2 - 2 } & $\mathrm{Mm}^{3} /$ year \\
\hline Quindío & 187.32 \\
\hline Navarco & 116.68 \\
\hline Boquerón & 17.34 \\
\hline Santo Domingo & 104.07 \\
\hline Verde & 56.76 \\
\hline
\end{tabular}

Source: [9]

This network spreads over a land shaped by volcanic ashes and different thermal floors, from occasional snow in the Quindío Volcano to the region of transitional semi-humid to semi-dry climate in La Vieja Valley; all the drainage network in the Department of Quindío belongs to La Vieja river basin [8] [9].

\section{Groundwater Supply}

The largest aquifer system fits the Quindío glacis, which expands from the northeast (Pereira, Filandia y Salento) to the west (La Tebaida, Caicedonia, Alcalá y Pereira): the second aquifer in importance is represented by the alluvial plain deposits (Qal) located in the flood plain of Barragán and La Vieja Rivers [9].

\section{E. Water Demand}

Water demand is subject to water licenses granted for the different uses of people along the river. Most of the water is used for water supply of settlements, industrial processes, and power generation. From all the licenses in the Department, Calarcá reports the highest demand with $8467.49 \mathrm{l} / \mathrm{s}$, followed by Armenia with $5261.49 \mathrm{l} / \mathrm{s}$. The largest amounts of water are directed to produce electric energy in the Little Hydroelectric Power Plants - PCH by its initials in Spanish- El Bosque with 3500 l/s and Campestre, Bayona, and La Unión with 2700 l/s each; for Armenia's aqueduct there is a license of $1500 \mathrm{l} / \mathrm{s}$ [8].

\section{Data Validation}

To validate meteorological and flow data, homogeneity test should be implemented. The most used pro- cedures to assess data homogeneity in engineering are: the runs test and the double mass curve [10]. For this study, the runs test and the double mass curve is applied to the nine meteorological stations selected. Also, this homogeneity analysis is performed to the four limnigraphic stations located in the jurisdiction of the Quindío river basin: Inlet EPA, Palestina Baja, Calle Larga, and Centro de la Guadua (Fig. 2).

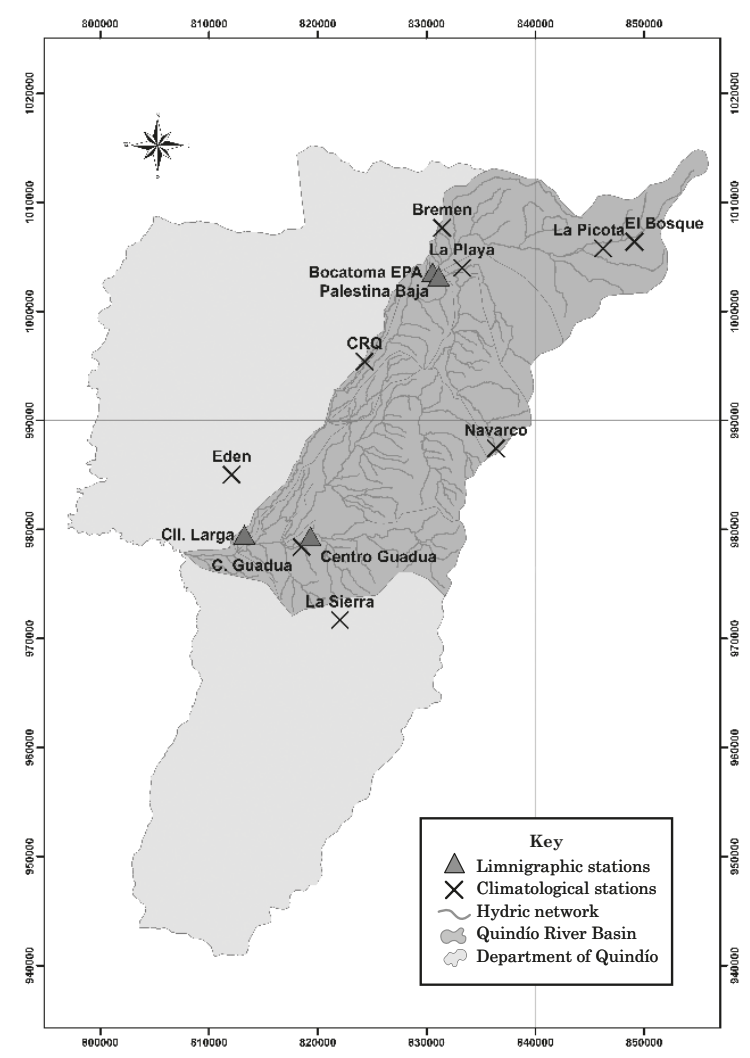

Fig. 2. Map of Hydroclimatological Stations Source: Author

Using the results from both tests, besides the uncertainty calculation for the most representative stations, it could be established that hydroclimatological data, despite some missing information in the time series, is suitable for the development of this research. Mean uncertainty values are below a 7\%, which is under the recommended standard values for meteorological and limnigraphic stations (literature establishes a range of $5-10 \%$.

Within the information collected from the flowmetering sites in March, 2010, a strong El Niño phenomenon was evidenced in the region, explaining the low values and the lack of concurrence with the values from the simulated and environmental flows. In contrast, September's flowmetering shows a seasonal condition characterized by La Niña phenomenon, providing greater discharge values than those from the ones normally registered for this site. 


\section{Restoration of the Natural Flow Regime in the Quindío River Basin}

For the restoration of the NFR in the Quindío basin, WEAP's DSS as hydrological model was applied; this is a spatially continuous modeling with a study area configured as a set of sub-basins covering all the extension of the basin analyzed. A set of homogeneous climatological data (precipitation, temperature, relative humidity, and wind speed) and physical information related to the area and the different types and/or morphology of soil is introduced to the model to be processed for each sub-basin studied. WEAP is a quasi-one-dimensional system that has two water balance buckets to be used for each type of soil use/morphology. It classifies water as runoff, infiltration, evaporation, baseflow, and percolation. The values of each area are added to obtain the cumulative values for each sub-basin [7] [11] [12] [13] [14] (Fig. 3).

DSS WEAP has three methods integrated to simulate hydrological processes: irrigation method, FAO's rainfall-runoff, and rainfall-runoff (Soil Moisture Method). As hydroclimatological data and the characteristic parameters of soil are limited, FAO's rainfall-runoff [12] method is implemented to perform the study in this basin, which, using mass balance, estimates evapotranspiration for irrigation purposes and surface runoff as streamflow; the latter is the most valuable variable to estimate environmental flows.

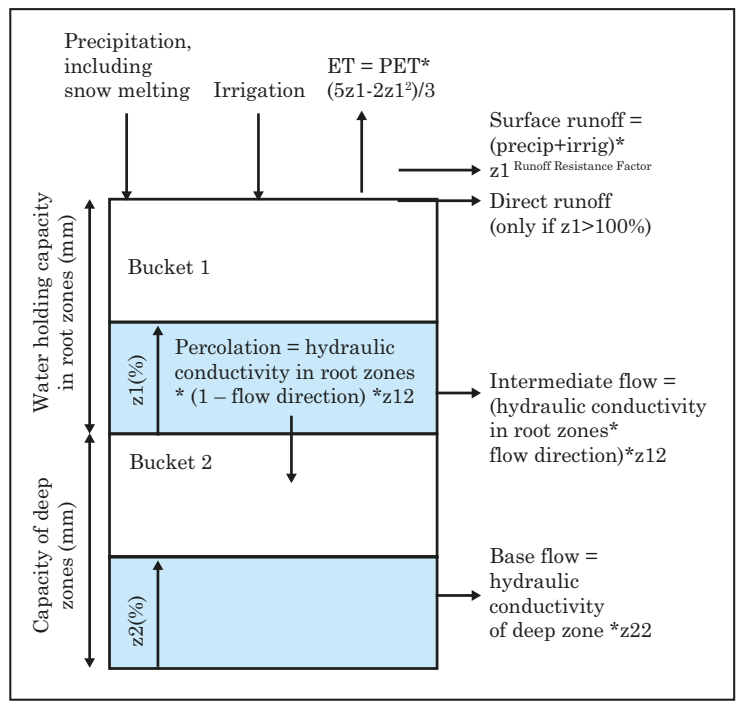

Fig. 3. Hydrological Elements Modeled in WEAP. Source: [13]

\section{A. Rainfall-runoff Method (FAO)}

This method determines potential evapotranspiration using crop coefficients $(\mathrm{Kc})$. The surplus of ra- infall not consumed by evapotranspiration is simulated as runoff, which, in turn, can be distributed between surface runoff and infiltration to groundwater [7] [11] [12].

\section{B. WEAP Hydrologic Method Calibration}

Calibration seeks to obtain a set of hydrologic and operational parameters to achieve the representation of flows and infrastructure operations that truly resemble time series. The calibration of this modeling will be performed through Nash Sutcliffe Efficiency (NSE) and PBIAS statistics formulated by [15]. NSE determines the relative magnitude of the residual variance (noise) compared to the measured data variance (information). PBIAS assesses bias by measuring the average tendency of the simulated data to be larger or smaller than their observed counterparts. This can be observed in (1) and (2):

$$
\begin{aligned}
& N S E=1-\left[\frac{\sum_{i=1}^{n}(Y i, \text { obs }-Y i, \text { sim })^{2}}{\sum_{i=1}^{n}(Y i, o b s-Y, \text { mean })^{2}}\right] \\
& P B I A S=\left[\frac{\sum_{i=1}^{n}(Y i, o b s-Y i, \text { sim }) * 100}{\sum_{i=1}^{n}(Y i, o b s)}\right]
\end{aligned}
$$

Where

Yi, obs: observed flow in the month $i$

Yi, sim: simulated flow in the month $i$

Yi, mean: mean flow observed in the period of analysis

\section{Restoration of the Natural Flow Regime}

Once the hydrological method has been calibrated in the DSS WEAP, and using the flowmetering information, the NFR of the river can be restored, this is, the river's discharge in the absence of any kind of exploitation. In order to achieve a better characterization of the Quindío River, it was divided into 14 sections shown in Table V and Fig. 4. Likewise, this restoration was completed for the four limnigraphic stations located in the Quindío basin jurisdiction.

DSS WEAP helps in this restoration by assuring simple procedures in the process. A scenario was created within the calibrated hydrological model; the data regarding water demand was changed for each unit of demand, both for urban demand and the hydroelectric power plant. The absence of water exploitation was assumed, so the value for water demand in the river will be zero (0). When running the model with this change, the DSS WEAP performs the water balance analysis for each section of the river and the NFR derives as a result, just as seen in Fig. 5 and 6 . 
INGE CUC, vol. 11 no. 2, pp 34-48, July - December, 2015

Table V. Identification Of Sections in the Quindío River

\begin{tabular}{|c|l|l|}
\hline Section & From & To \\
\hline 1 & Source of the Quindío River Salento municipality & Inlet EPA \\
\hline 2 & Inlet EPA & Confluence with Navarco River \\
\hline 3 & Confluence with Navarco River & PCH Campestre \\
\hline 4 & PCH Campestre & PCH Bayona \\
\hline 5 & PCH Bayona & Inlet of La Tebaida municipality aqueduct \\
\hline 6 & Inlet of La Tebaida municipality aqueduct & PCH La Unión \\
\hline 7 & PCH La Unión & Confluence with La Florida stream \\
\hline 8 & Confluence with La Florida stream & Return flow San Nicolas stream municipality of Armenia \\
\hline 9 & Return flow San Nicolas stream municipality of Armenia & Return flow PCH La Unión \\
\hline 10 & Return flow PCH La Unión & Confluence with El Pescador stream \\
\hline 11 & Confluence with El Pescador stream & PCH El Bosque \\
\hline 12 & PCH El Bosque & Return flow PCH El Bosque \\
\hline 13 & Return flow PCH El Bosque & Confluence with Verde River \\
\hline 14 & Confluence with Verde River & Intersection Barragán- La Vieja River \\
\hline
\end{tabular}

Source: Author

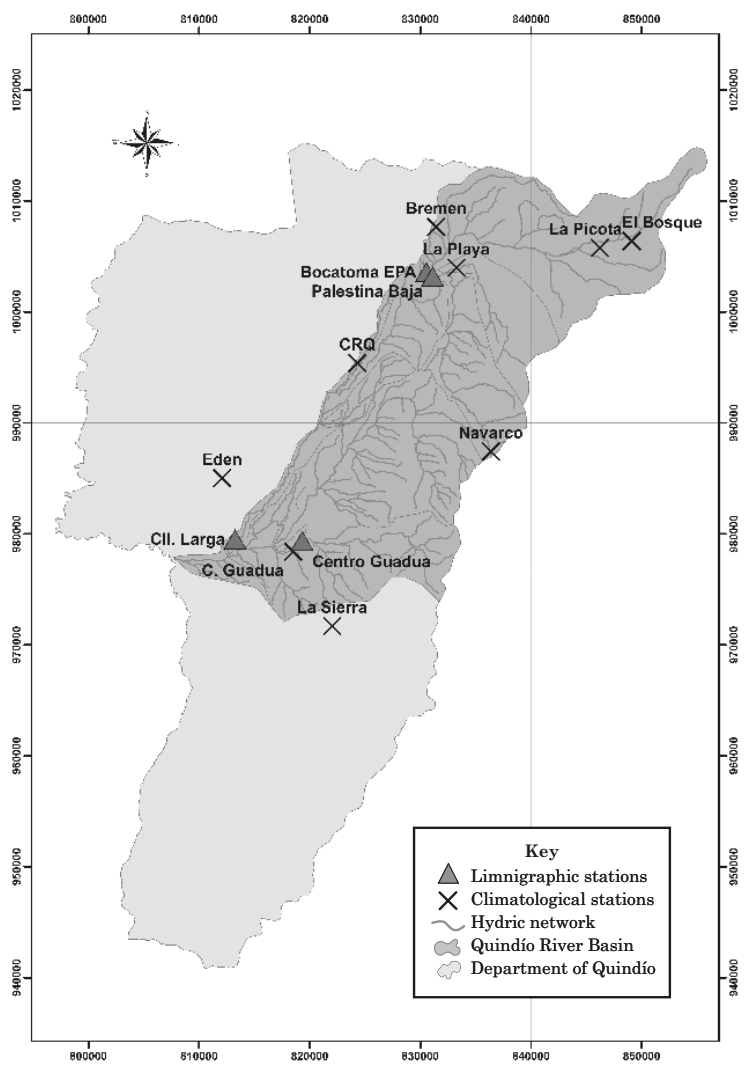

Fig. 4. Location of in the Quindío River. Source: Author

These figures show the comparison between the flow rates of the calibrated models and the restoration of NFR for some of the mentioned sections.

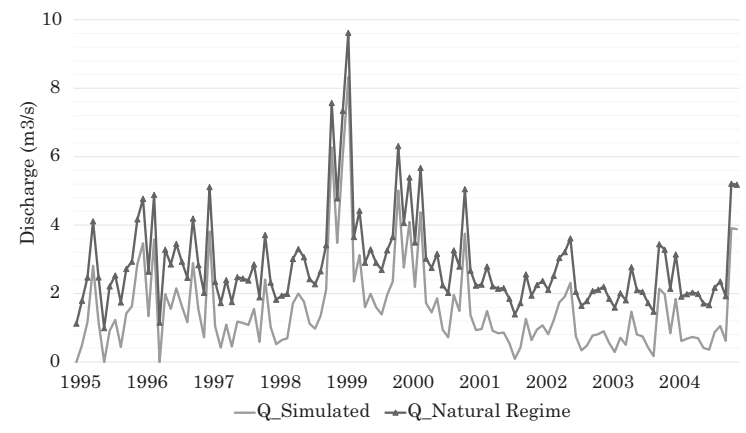

Fig. 5. Simulated Flow and Restored NFR. Section 2 Source: Author

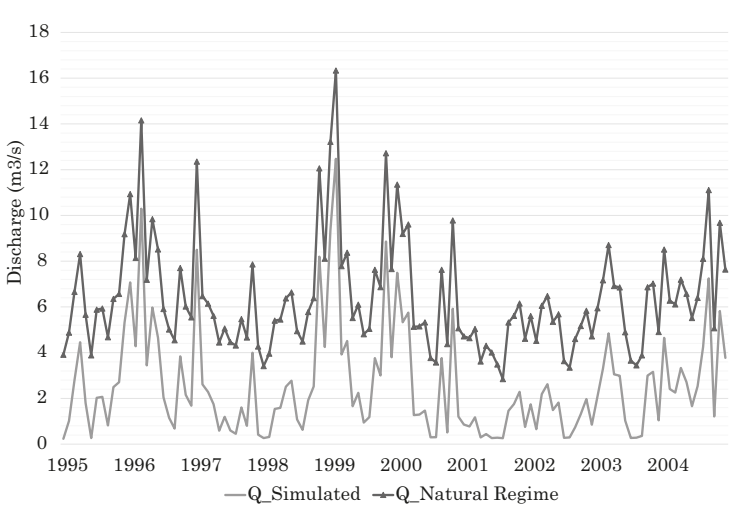

Fig. 6. Simulated Flow and Restored NFR. Section 8. Source: Author

As shown, in both figures, NFR is higher than the flow rates. This difference corresponds to the water demand of the river basin in each of the sections stu- 
died. With the NFR estimated, environmental flows are determined using the abovementioned methods so as to define which is the most appropriate for the hydroclimatological conditions of the Quindío River basin.

\section{Method Performance and Results}

To carry out the different methods a complete time series is necessary. In this case, daily discharge records of the Quindío River for a period of 10 years (1995-2004) were used. Additionally, the monthly average of the daily data series and some data obtained using statistical estimations (intrannual and interannual means, Q300, and Q347) were also used [1] [5] [6]. The mean intrannual discharge is the average of the daily discharges annually classified, and the mean interannual discharge is the average of the daily discharges of the whole time series.

In Table VI, a distribution of the hydrologic and hydraulic methods is shown in a time scale.

Table VI. Method Timescale

\begin{tabular}{|c|c|c|}
\hline \multicolumn{3}{|c|}{ Timescale of the Methods Applied } \\
\hline $\begin{array}{c}\text { Monthly } \\
\text { Scale }\end{array}$ & $\begin{array}{c}\text { Annual } \\
\text { Scale }\end{array}$ & $\begin{array}{c}\text { Daily } \\
\text { Scale }\end{array}$ \\
\hline Texas & Matthey 1 (Q347) & 7 Q10 \\
\hline Utah & Matthey 2 (Q347) & $\cdots$ \\
\hline NGPRP & Matthey 3 (Q347) & $\cdots$ \\
\hline AFC & DGOH Spain & $\cdots$ \\
\hline Navarrese & Swiss & $\cdots$ \\
\hline Basque & Asturian & $\cdots$ \\
\hline Tessman & Q90 & $\cdots$ \\
\hline Q95 & Q97.5 & $\cdots$ \\
\hline$\cdots$ & IDEAM & $\cdots$ \\
\hline$\cdots$ & Hoppe & $\cdots$ \\
\hline
\end{tabular}

Source: Author

The main objective of this study is to determinate environmental flows downstream from the different water exploitation structures and catchments along the principal streamflow of the Quindío River. In the application of the methods for environmental flow estimation, the sections of the river where there is more water and environmental pressure are emphasized. These are: Armenia's inlet, managed by EPA, located in the high section of the basin; the alternative inlet for the municipality of Armenia (EPA pumping station), catchments from El Campestre, Bayona, La Unión, and El Bosque PCH; and the inlet in La Tebaida municipality (the latter are in the middle section of the basin).
The environmental flows from two of the main tributaries will also be estimated: Navarco and Green rivers; respectively, where the Palestina Baja and Centro de la Guadua limnigraphic stations are.

Environmental flow estimation was performed along the principal streamflow of the river for the fourteen sections defined, however, only the results from two relevant sections will be presented: the section covering the source of the river and Armenia's inlet, and the section of the Navarco's mouth, where a dam is likely to be built. It is important to highlight that results from the remnant sections are presented in the same way.

\section{A. Quindío River Source-EPA Inlet}

Currently, this section has a water catchment structure managed by EPA in order to provide and distribute this resource to the Armenian population. Likewise, other activities are also using the water resource of the river: fish hatcheries, agriculture, Salento's municipal aqueduct, and several rural district aqueducts. Fig. 7 illustrates the time series of daily discharge values for the section aforementioned.

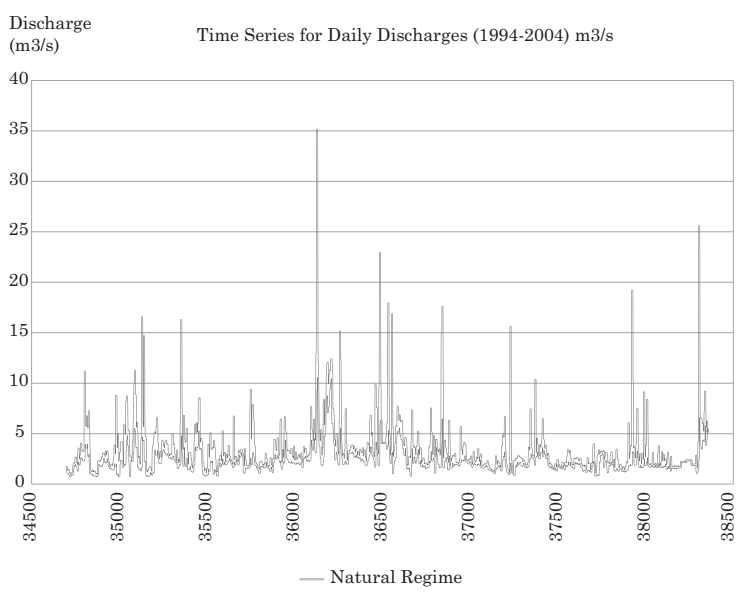

Fig. 7. Time Series of Daily Discharges in the EPA Inlet 1995-2004. Source: Author

\section{1) Monthly Scale Results of the Methods}

Fig. 8 shows a variable behavior throughout the different months, demonstrating that the most conservative methods are the Flow Duration Analysis, the Northern Great Plains Resource Program (NGPRP), and the Utah methods.

The Q95 method stays on the mean values of the different methods, and keeping a uniform behavior. This method is quite important since it constitutes one of the presented by [3] and [6] for the estimation and assessment of environmental flows in projects requiring environmental licenses. 


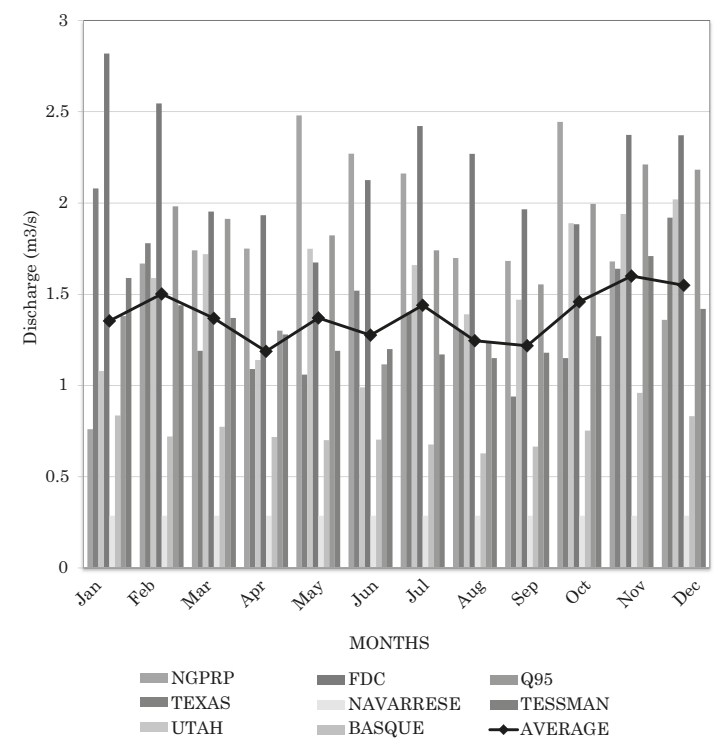

Fig. 8. Monthly Scale Comparison of Methods - EPA Inlet. Source: Author

\section{2) Annual Scale Results of the Methods}

Annual scale methods are inadequate, since hydrological behavior of rivers varies throughout the year, hence, it is not recommended to establish a baseflow for the whole year. Fig. 9 shows the behavior of methods on an annual basis for the EPA inlet station.

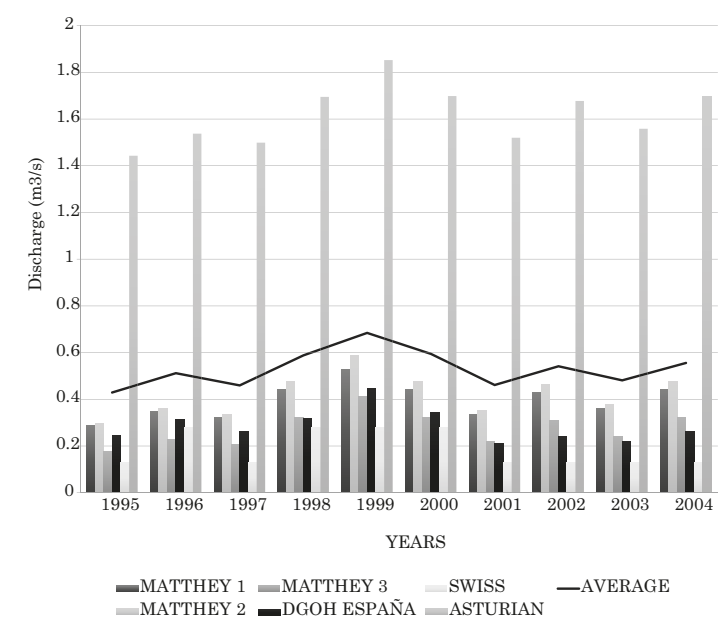

Fig. 9. Annual Scale Comparison of Methods (EPA Inlet) 1995 -2004. Source: Author

\section{B. Limnigraphic Station Palestina Baja Navarco River}

This section is fundamental for this study because a Multi-purpose dam will likely be built there, thus, creating a socioeconomic and environmental impact in the region. Environmental flow estimation will provide the entities involved in the project a tool to assess the impact on water demand and, in this way, make suitable decisions to preserve life in this section of the river.

It can be observed in Table VII that Q95, Flow Duration, and NGPRP methods are the most conservative for a monthly scale; so, Q95 becomes the most important in the analysis. Also, the Basque and Navarrese methods are shown as very flexible, generating doubts on whether the river would manage to keep the physical and habitat conditions needed to sustain the aquatic fauna and flora.

Table VIII presents the results of the different methods on an annual basis for the limnigraphic station of Palestina Baja in the Navarco River.

Table IX sets forth the results of the methods applied in Colombia. These use unusual timescales, preventing from classifying them in a daily, monthly, or annual timescale. These methods provide exact data for every section of the river.

\section{Result Analysis}

The analysis of results is executed for the most relevant points or sections of the river basin. They characterize for their particular hydraulic and environmental conditions and their direct implications with the streamflow.

\section{A. EPA Inlet Section}

Fig. 10 illustrates the curves of the different discharges estimated during the development of the study: the discharge in a natural regime condition, the discharge registered at the limnigraphic station, the flow rate (after catchment), and the environmental flow recommended for the sections downstream from the EPA inlet using the Q95 method.

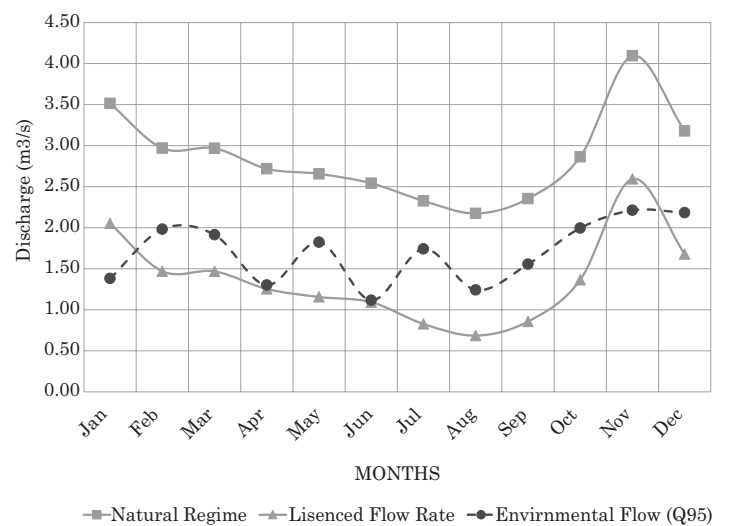

Fig. 10. Comparison of Natural Flow Regime, Real Flow Rate, and Environmental Flow at EPA Inlet Source: Author 
ENVIRONMENTAL FLOW ESTIMATION USING HYDROLOGICAL AND HYDRAULIC

METHODS FOR THE QUINDÍO RIVER BASIN: WEAP AS A SUPPORT TOOL

Table ViI. Comparison of Environmental Flow Methods in a Monthly Scale (M³/S) Palestina Baja Station (Navarco River)

\begin{tabular}{|l|c|c|c|c|c|c|c|c|c|c|c|c|}
\hline \multicolumn{1}{|c|}{ Method } & JAN & FEB & MAR & APR & MAY & JUN & JUL & AGO & SEP & OCT & NOV & DIC \\
\hline Texas & 1.54 & 1.54 & 1.08 & 1.11 & 1.03 & 1.47 & 1.17 & 1.33 & 0.92 & 0.72 & 1.18 & 1.53 \\
\hline Utah & 1.12 & 1.11 & 1.24 & 1.13 & 1.19 & 1.22 & 1.08 & 1.12 & 1.38 & 1.10 & 2.43 & 1.52 \\
\hline NGPRP & 1.51 & 1.52 & 1.45 & 1.18 & 1.95 & 1.83 & 1.19 & 1.16 & 1.39 & 1.70 & 2.13 & 1.75 \\
\hline FDC & 2.34 & 2.34 & 2.55 & 2.63 & 2.47 & 2.36 & 1.88 & 1.88 & 2.14 & 1.64 & 2.21 & 2.36 \\
\hline Navarrese & 0.24 & 0.24 & 0.24 & 0.24 & 0.24 & 0.24 & 0.24 & 0.24 & 0.24 & 0.24 & 0.24 & 0.24 \\
\hline Basque & 0.71 & 0.72 & 0.75 & 0.76 & 0.73 & 0.68 & 0.56 & 0.59 & 0.60 & 0.53 & 0.83 & 0.74 \\
\hline Tessman & 1.19 & 1.19 & 1.23 & 1.27 & 1.19 & 1.17 & 1.05 & 1.16 & 1.19 & 0.98 & 1.18 & 1.17 \\
\hline Q95 & 1.27 & 1.25 & 1.47 & 1.33 & 1.39 & 1.40 & 1.22 & 1.39 & 1.70 & 1.17 & 2.51 & 1.65 \\
\hline Average & 1.24 & 1.24 & 1.25 & 1.21 & 1.27 & 1.30 & 1.05 & 1.11 & 1.20 & 1.01 & 1.59 & 1.37 \\
\hline
\end{tabular}

Source: Author

Table ViII. Comparison of Environmental Flow Methods in an Annual Scale (M³/S) Palestina Baja Station (Navarco River)

\begin{tabular}{|l|c|c|c|c|c|c|c|c|c|c|}
\hline \multicolumn{1}{|c|}{ Method } & 1995 & 1996 & 1997 & 1998 & 1999 & 2000 & 2001 & 2002 & 2003 & 2004 \\
\hline Matthey 1 (Q347) & 0.31 & 0.45 & 0.48 & 0.39 & 0.45 & 0.31 & 0.32 & 0.38 & 0.41 & 0.44 \\
\hline Matthey 2 (Q347) & 0.32 & 0.49 & 0.53 & 0.41 & 0.49 & 0.32 & 0.34 & 0.41 & 0.43 & 0.47 \\
\hline Matthey 3 (Q347) & 0.2 & 0.33 & 0.36 & 0.27 & 0.33 & 0.19 & 0.21 & 0.26 & 0.29 & 0.32 \\
\hline DGOH Spain & 0.25 & 0.35 & 0.23 & 0.2 & 0.25 & 0.16 & 0.15 & 0.17 & 0.27 & 0.42 \\
\hline Swiss & 0.13 & 0.28 & 0.13 & 0.13 & 0.13 & 0.13 & 0.13 & 0.13 & 0.13 & 0.28 \\
\hline Asturian & 1.32 & 1.37 & 1.31 & 1.3 & 1.32 & 1.28 & 1.28 & 1.29 & 1.33 & 1.4 \\
\hline Average & 0.42 & 0.55 & 0.51 & 0.45 & 0.5 & 0.4 & 0.41 & 0.44 & 0.48 & 0.56 \\
\hline
\end{tabular}

Source: Author

Table IX. Environmental Flow Methods Applied in Colombia (M³/S)

\begin{tabular}{|c|c|c|c|c|}
\hline Section & IDEAM $^{1}(2004)$ & $\mathrm{ENA}^{2}(2004)$ & WATER BILL ${ }^{3}$ (2005) & $7 Q 10$ \\
\hline EPA Inlet & 0.54 & 0.80 & 1.00 & 0.84 \\
\hline Navarco & 0.45 & 1.03 & 1.27 & 0.96 \\
\hline 2 & 0.54 & 0.80 & 1.00 & N.A \\
\hline 3 & 1.15 & 3.49 & 4.15 & N.A \\
\hline 4 & 1.15 & 3.49 & 4.15 & N.A \\
\hline 5 & 1.15 & 3.49 & 4.15 & N.A \\
\hline 6 & 1.15 & 3.49 & 4.15 & N.A \\
\hline 7 & 1.15 & 3.49 & 4.15 & N.A \\
\hline 8 & 1.15 & 3.52 & 4.19 & N.A \\
\hline 9 & 1.15 & 3.52 & 4.19 & N.A \\
\hline 10 & 1.15 & 3.52 & 4.19 & N.A \\
\hline 11 & 1.15 & 3.52 & 4.19 & N.A \\
\hline 12 & 1.17 & 3.57 & 4.30 & N.A \\
\hline Calle Larga & 1.17 & 3.57 & 4.30 & 8.05 \\
\hline 14 & 2.18 & 7.00 & 7.87 & N.A \\
\hline C. Guadua & 0.41 & 1.04 & 1.32 & 0.52 \\
\hline
\end{tabular}

N.A: Not applicable Source: Author 
According to results of the environmental flow and the flow rates after the EPA inlet catchment, a great impact is evidenced after this point regarding the development and sustainability of the aquatic fauna and flora because for 10 months of the year, except December and January, the values for environmental flows established in this study are not met. The most critical period is August when the difference between the environmental flow $(1.24 \mathrm{~m} 3 / \mathrm{s})$ and the flow rate downstream the catchment structure $(0.45 \mathrm{~m} 3 / \mathrm{s})$ is 0.78 $\mathrm{m} 3 / \mathrm{s}$.

Due to this, it is strongly recommended that as of the moment EPA's pumping station starts operating in the rural district of Chagualá, in the municipality of Calarcá, for low water seasons, an alternative catchment structure located between Salento's inlet and the pumping station should be built in order to improve aquatic flora and fauna conditions.

\section{B. EPA Pumping Station Section}

Fig. 11 illustrates the curves for discharge at a natural flow regime condition, flow rates, environmental flow (Q95), and the average of some specific flow meterings taken at the EPA pumping station inlet. It is important to mention that for this station, the values for environmental flow behavior (Q95) during most of the year are below those established for flow rates using DSS WEAP. So far, this section is achieving the environmental flow parameters established in this study, however, EPA pumping station is not operating to date. Hence, special care will be necessary when operation starts, i.e. environmental flow criteria needs to be verified to confirm this will be granted.

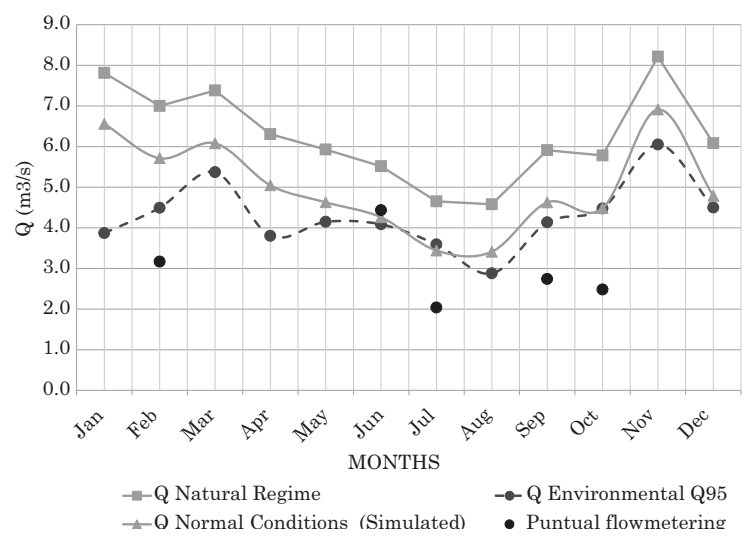

Fig.11. Comparison of Natural Flow Regime, Real Flow Rate, and Estimated Environmental Flow at EPA Pumping Station Source: Author

\section{Section Before PCH Campestre Discharge}

In this section the PCH Campestre has a license for $2.7 \mathrm{~m} 3 / \mathrm{s}$. This has affected flow rates and hydraulic and biologic conditions considerably. As shown in Fig. 12, the environmental flow (Q95) in this section is superior to the flow rate simulated with DSS WEAP, thus, environmental flow standards are not being accomplished. In this order of ideas, environmental authorities must develop joint strategies with users of this resource to reduce the difference between these two curves and improve aquatic flora and fauna conditions.

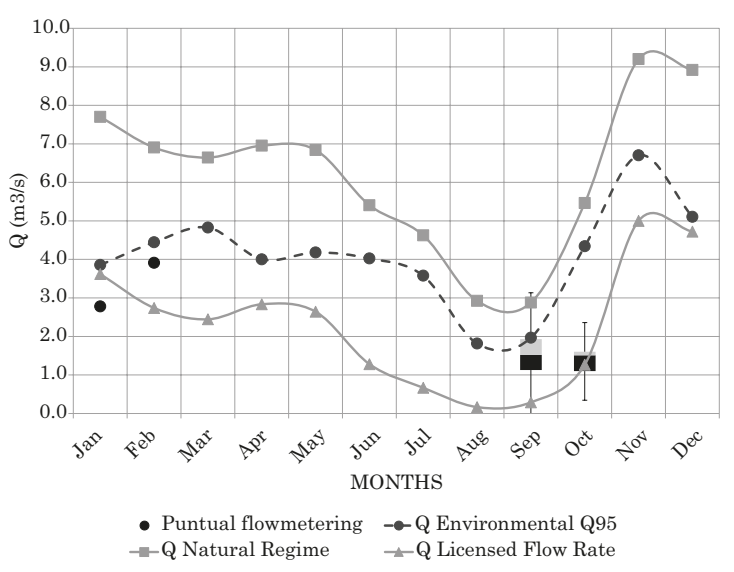

Fig. 12. Comparison of Natural Flow Regime, Flow Rate, and Environmental Flow in the Section before PCH Campestre Discharge Source: Author

It is also important to indicate that this water unbalance between the environmental flow and the flow rate is constant throughout the whole river basin (from EPA's pumping station to the $\mathrm{PCH}$ El Bosque), however, this section represents the area with the highest water exploitation due to the catchments from La Tebaida municipality and the PCH El Campestre, Bayona, La Unión, and El Bosque. The greatest impact is reported in La María, between the municipalities of Armenia and Calarcá.

Fig. 13 shows the curves of the flows analyzed (natural regime, flow rate, environmental flow, and some punctual flowmeterings) from the inlet sector in the municipality of La Tebaida. As appreciated, environmental flow values are above the ones of the flow rate, showing that in the middle Quindío River basin the environmental flow standards are not fulfilled. Again, environmental authorities and users must develop mitigation strategies so as to improve the environmental condition of the river's flora and fauna. 


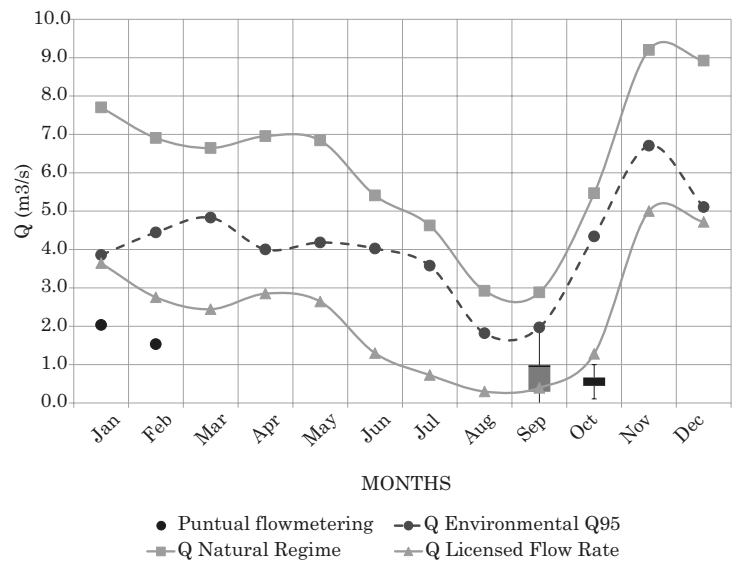

Fig.13. Comparison of Natural Flow Regime, Flow Rate, and Environmental Flow in La Tebaida Inlet Source: Author

\section{Calle Larga Limnigraphic Station}

Results for this section of the river (lower Quindío River basin) manifest higher discharges from those observed in the middle river basin, where there is more water exploitation. Fig. 14 illustrates the curves for the values of natural regime, flow rate, environmental flow, and specific flow meterings taken at the Calle Larga limnigraphic station. Hence, this section has an adequate environmental flow, mainly due to the lack of significant catchment structures, and also because the licensed flow $(3.5 \mathrm{~m} 3 / \mathrm{s})$ has been discharged upstream to the $\mathrm{PCH}$ for energy generation. Similarly, through the hydrologic modeling of the basin with the DSS WEAP, the hydraulic interconnection between the Quindío glacis aquifer and the Quindío River was assumed as existent, thus, providing more discharge in the streamflow for this section.

There are not restrictions for water catchments in this point considering that discharge values are rather high, so hydrological and environmental emergencies can be avoided in the river. Nonetheless, water in this point is not suitable for human consumption due to the high pollution levels produced upstream, where wastewater from the urban area of Armenia is discarded, as well as from El Caimo, tanneries and households from La María, abattoirs from Armenia, etc. On the other hand, this resource is ideal for agricultural uses (not including primary crops) because of its high nutrient concentration.

The results obtained in this study indicate environmental flows need to be established in the different sections of the Quindío River, this means, principles that allow a comprehensive management of water in the basin need to be set up by the Basin Management Unit -UMC by its acronym in Spanish.

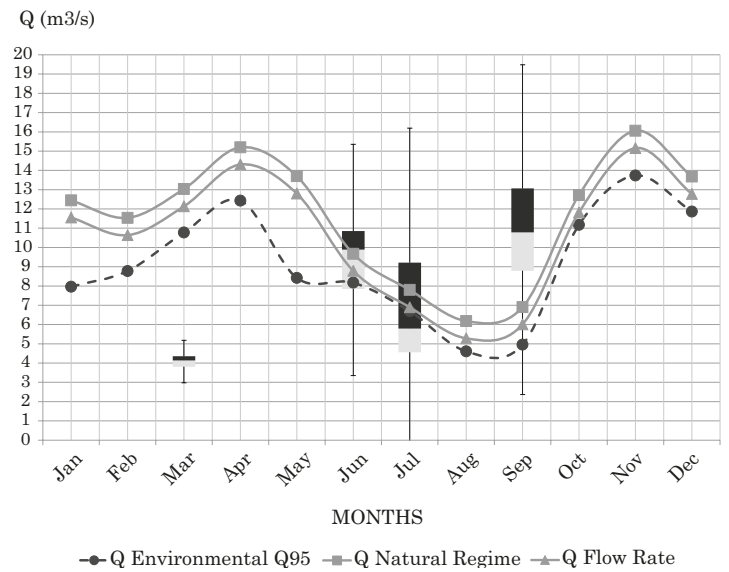

Fig. 14. Comparison of Natural Flow Regime, Flow Rate, and Environmental Flow in Calle Larga Limnigraphic Station Source: Author

VIII. Advisory Tool For Environmental Flows And Licensing: ArcGis

A Geographic Information System database, ArcGIS 9.3, was created as a complementary tool for environmental flow determination. Its hydroinformatic approach was used to consult environmental flows by the Quindío River UMC.

With this database, water resource planners can consult, make reports, and elaborate graphs based on the data introduced regarding environmental flows; these can be performed for any particular point or section of the river, as shown in Fig. 15.

\section{Conclusions And Recommendations}

Monthly-scaled methodologies for environmental flow estimation are very conservative and present a better adjustment for flow regimes in the Quindío River Basin.

Methods applied in Colombia, such as [16] and [17], produce specific values that do not describe the real seasonal variations of rainfall and flow regimes. These precise values produce uncertainty in regard to the efficiency of the abovementioned methods, hence, monthly-scaled methods are recommended to capture flow regime behavior. For the specific case of the Quindio River Basin, the best adjustment for hydrological behavior is delivered by the Q95 method.

In conclusion, for the case that concerns us, Q95 method presents an environmental flow regime that adjusts to the climatological variability of the region. Concerning the method 7Q10, the punctual values are not adjusted to the climatological variation of the region, thus, it is strongly recommended that environmental authorities select the environmental flow defined with the results obtained from the Q95 method. 


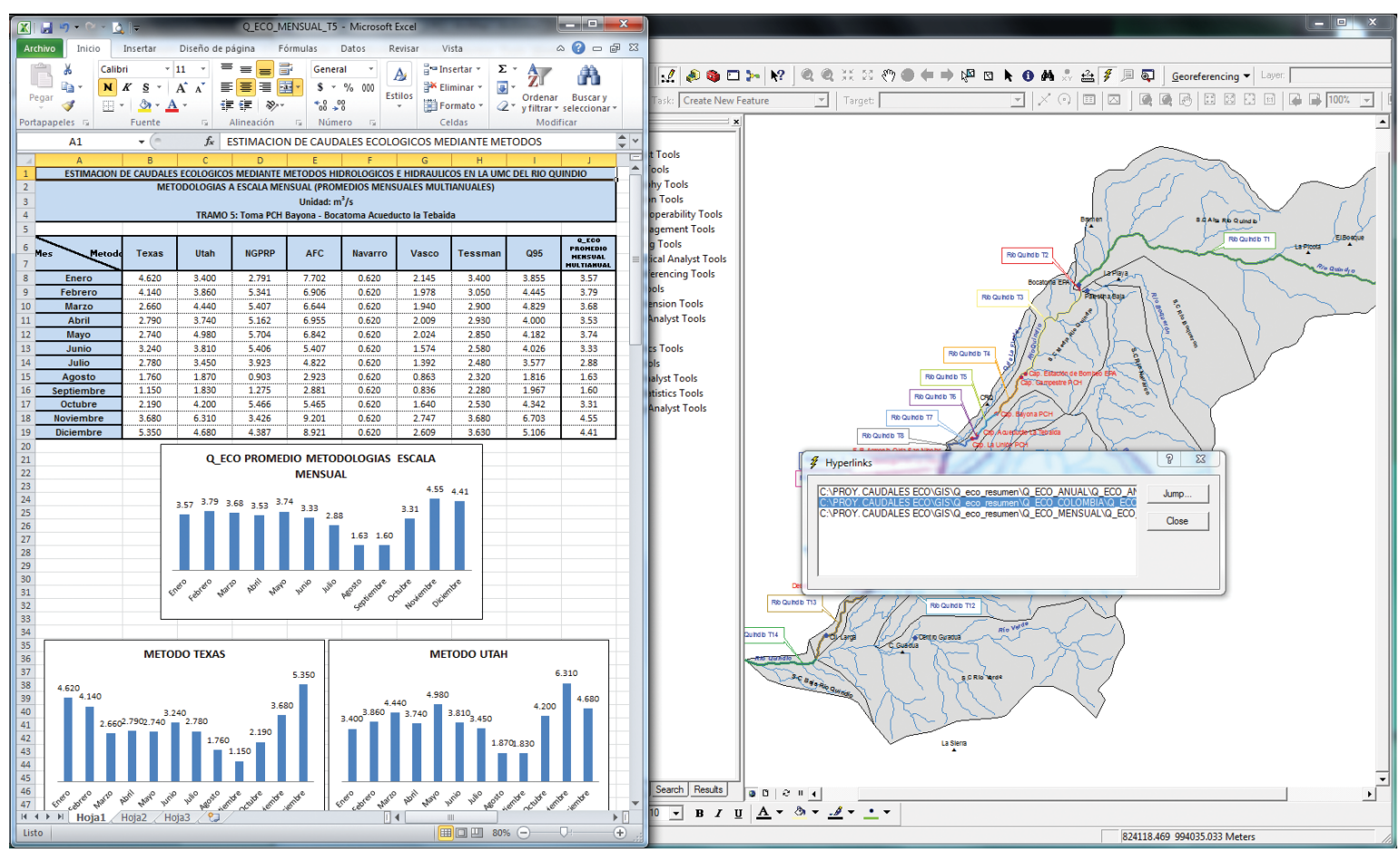

Fig. 15. Environmental Flow Analysis from Sections and Points of the Quindío River Source: Author

Environmental flow values obtained for the $\mathrm{Na}$ varco River and the EPA inlet sections evidence the problems that can arise during low water seasons regarding the amount of water for human consumption. This problem may cause seasonal droughts in the river if the distribution of resource is not planned.

In the Middle Quindío River Basin and during low water season, the river is more affected by the permanent catchments from the $\mathrm{PCH}$, creating a devastating impact in the sections previously mentioned.

Based on the results obtained with the FAO's rainfall-runoff method and the flow metering in the limnigraphic stations of Quindío River, it can be concluded that there is a hydraulic interconnection between the Quindío Glacis aquifer and the Quindío River. Unfortunately, there are not any studies about aquifers in order to have a better idea of its behavior and interaction with the surface streams of the basin.

During low water season, it is advised that the hydroelectric power plants located in the Middle Quindío River Basin capture a maximum of a $50 \%$ of the total value licensed so as to avoid any major hydric stress in the basin.

The Q95 method is suggested when planning and licensing water exploitation in any section or point of the river because as it uses a monthly scale, it represents hydrological and seasonal behavior better.
Local planners of the water resource will find in ArcGIS a useful hydroinformatic tool that will allow them to make decisions regarding management and allocation of the available water.

This research is fundamental for a comprehensive management of water resources and for considering hydroclimatological, socioeconomic, morphological, and seasonal aspects of the Quindío River so as to incorporate them into an organized management scheme where water resources and the environment are protected, mainly, by a rational and efficient use of water and the actors involved.

For the validation of this study, an environmental flow analysis needs to be executed under the concept of habitat simulation in order to establish, through the inclusion of the habitat features of each living species and their demands, an environmental flow that satisfies the needs of such species and preserves the morphological and environmental conditions of the Quindío River Basin.

\section{REFERENCES}

[1] G. Lozano, Caudales Ecológicos: Conceptos, Metodologías, Estado del Arte y estimación mediante métodos hidrológicos. Departamento de Ingeniería Hidráulica y Medio Ambiente, Universidad Politécnica de Valencia, 2005 .

[2] Ministerio de Ambiente Vivienda y Desarrollo Territorial, Resolución 865 de 2004. 


\section{ENVIRONMENTAL FLOW ESTIMATION USING HYDROLOGICAL AND HYDRAULIC METHODS FOR THE QUINDÍO RIVER BASIN: WEAP AS A SUPPORT TOOL}

[3] Universidad Nacional de Colombia and Grupo GIREH, Metodología para la estimación de caudal ambiental en proyectos licenciados, Santa fe de Bogota, 2008.

[4] J. M. Diez-Hernández and L. Burbano Burbano, "Advanced techniques for evaluating instream flows in sustainable watershed management," Ing. e Investig., vol. 26, no. 1 , pp. $58-68,2006$

[5] J. M. Diez and D. H. Ruiz, "Determinación de Caudales Ambientales confiables en Colombia: el ejemplo del río Palacé (Cauca)," Gestión y Ambiente, vol. Vol. 10, pp. 153-166, 2007.

[6] F. Magdaleno Mas, Caudales Ecologicos: Conceptos, Metodos e Interpretaciones, 1st Ed. Centro de Estudios y Experimentacion, 2005.

[7] Stockholm Environment Institute, Centro de Cambio Global (UG), and U. C. de Chile, Guía Metodológica de Modelación Hidrológica y de Recursos Hídricos con el Modelo WEAP, Stockholm Environment Institute (SEI), 2009 .

[8] Corporación Regional del Quindio, "Plan de ordenación y manejo ambiental UMC río Quindío,” 2008.

[9] CRQ, CVC, CARDER, UAESPNN, MAVDT, IDEAM, and GTZ, "Plan de ordenación y manejo de la cuenca hidrográfica del río La Vieja,” CRQ, 2007.
[10] V. T. Chow, D. R. Maidment, and L. W. Mays, Hidrología Aplicada, Bogotá, 1994

[11] FAO, "Caracterización social, ambiental y productiva e identificación de los actores del sector forestal de los departamentos del Eje Cafetero, Antioquia, Tolima y Valle del Cauca," 2005

[12] Fao, "Evapotranspiración del cultivo," Organización de las Naciones Unidas para la Agricultura y la Alimentación, 2006.

[13] J. Sieber and D. Purkey, Water Evaluation And Planning System USER GUIDE, 1st ed. Somerville: Stockholm Environment Institute, 2007.

[14] J. Sieber and D. Purkey, Water Evaluation And Planning System Tutorial, 1st ed. Somerville: Stockholm Environment Institute, 2010

[15] D. N. Moriasi, J. G. Arnold, M. W. Van Liew, R. L. Bingner, R. D. Harmel, and T. L. Veith, "Model evaluation guidelines for systematic quantification of accuracy in watershed simulations," Natl. Agric. Libr., vol. 50, no. 3, pp. 885-900, 2007

[16] Ministerio de Ambiente Vivienda y Desarrollo Territorial, Proyecto de Ley Numero 365, 2005.

[17] IDEAM, Estudio Nacional del Agua, Instituto de Hidrologia, Meteorologia y Estudios Ambientales, 2004 